\title{
PERMAINAN TRADISONAL LOJO (PALEJO) DARI PROVINSI SULAWESI TENGGARA DAN PEMBENTUKAN KARAKTER KERJA KERAS PADA PESERTA DIDIK SD/MI DI INDONESIA
}

\author{
Nidha Yulianti, Anis Fuadah Z \\ Program Studi Pendidikan Guru Madrasah Ibtidaiyah \\ Fakultas Ilmu Tarbiyah dan Keguruan UIN Syarif Hidayatullah Jakarta \\ Nidhayulianti92@gmail.com
}

\begin{abstract}
Abstrak
Permainan tradisional banyak yang mengandung nilai- nilai karakter, namun pada saat ini permainan tradisional tersebut semakin tergantikan oleh permainan digital seperti game online, playstation atau permainan yang terdapat di Handphone sehingga mempengaruhi karakter anak. Akibatnya mereka tidak memperdulikan kehidupan disekelilingnya, seperti memiliki dunia sendiri dengan gadged-nya. Oleh karena itu, penelitian ini ditulis bertujuan untuk menggali dan mendeskripsikan nilai- nilai karakter dari permainan tradisional, yang salah satunya ialah Lojo /Palejo. Sehingga pada akhirnya dapat melestarikan permainan tradisional yang bermanfaat untuk menumbuhkan karakter anak. Fokus dalam penelitian ini adalah analisis nilai- nilai karakter yang terdapat didalam Lejo/Palejo khususnya pada siswa sekolah dasar. Hal ini dilatar belakangi pada usia ini merupakan usia bermain, maka kita perlu memberikan bimbingan tentang permainan yang baik untuk perkembangannya. Disamping itu, usia siswa sekolah dasar merupakan usia pembentukan kepribadian, sehingga penting sekali dilakukan penanaman karakter. Penelitian ini ditulis berdasar pada analisis studi pustaka. Hasilnya menunjukan bahwa permainan Lojo/Palejo dapat menanamkan dan membentuk nilai- nilai budaya dan membangun karakter anak seperti disiplin, jujur, mandiri, tanggungjawab, kerja keras, semangat, bersahabat, cinta damai dan musyawarah.
\end{abstract}

Kata Kunci : permainan tradisional, anak MI/ SD, Lojo (palejo), nilai karakter.

\begin{abstract}
Many traditional games contain character values. These traditional games are increasingly being replaced by digital games such as online games, playstations or games on mobile phones that affect children's characters. As a result they do not care about life around them, like having their own world with its gadged. Therefore, this study aims to explore and describe character values of traditional games, one of which is Lojo/Palejo. The end goal is to preserve traditional games that are useful for fostering children's character. The focus in this study is analysis of character values in Lejo/Palejo, especially for elementary school students. This is because children at that age need to provide guidance on appropriate game for their development. In addition, age of elementary school students is age of personality formation, so it is very important to implement character. This research is a literature study. The results show that Lojo/Palejo game can apply and shape cultural values also build children's character such as discipline, honesty, independence, responsibility, hard work, enthusiasm, friendship, love of peace and deliberation.
\end{abstract}

Keywords: traditional games, MI/SD children, Lojo (palejo), character values. 


\section{A. PENDAHULUAN}

Perkembangan IPTEK yang begitu pesat dalam era globalisasi menimbulkan perubahan tingkah laku yang berbeda pada manusia. Menurut Dahlian dkk, bahwa globalisasi dapat mempengaruhi kearifan local melalui pola pikir manusia. Dahulu segala sesuatu dilakukan secara manual namun sekarang segala sesuatunya serba canggih memasuki dunia digital. Jika dahulu untuk mendapatkan sesuatu seseorang harus pergi ke suatu tempat maka sekarang untuk mendapatkan apa yang kita mau cukup dengan oline saja. Berbagai kemudahan telah ditawarkan oleh dunia digital. Hal ini jauh berbeda dengan dengan zaman dahulu yang segala sesuatunya membutuhkan usaha dan upaya keras untuk mendapatkan apa yang kita mau.

Tidak hanya pada orang dewasa, kehidupan anak- anak pun juga terpengaruh dan mengalami perubahan dengan kemajuan teknologi saat ini. Anakanak sekarang, khususnya siswa sekolah dasar tidak lagi memainkan permainan tradisional. Bahkan anak- anak zaman sekarang tidak kenal dengan permainan kuno yang dimainkan oleh ayah dan ibunya pada zaman dahulu. Permainan-permainan berbasiskan mesin elektronik menjadi permainan yang sangat akrab bagi mereka. Sementara permainan- permainan yang asli bertumbuh dan berkembang dari akar cultural masyarakat Indonesia terpinggirkan oleh permainan- permainan modern berbasis mesin dan di impor dari negara lain. Permainan anak tradisional yang kaya akan nilai- nilai luhur budaya bangsa semakin tidak dikenal oleh anak- anak saat ini. Anak lebih akrab dengan game online, playsation, dan game elektronik lainnya dibandingkan permainan umpetan, engklek, gobak sodor, lojo palejo, cim-ciman dan permainan anak tradisional lainnya. ${ }^{1}$

Permainan modern terkesan keren menggunakan teknologi canggih dan mutakhir. Jika dibandingkan dengan permainan tradisional sangatlah jauh. Permainan tradisional hanya memerlukan alat- alat sederhana bahkan seadanya, bisa dari kayu, batu, serta bisa berupa batang dan daun dari tumbuh- tumbuhan. Untuk memainkan permainan tradisional terkadang tidak membutuhkan alat apaapa, cukup dengan menggerakkan tubuh saja.

${ }^{1}$ Wafiq Nurul Huda, Pembentukkan Karakter Pada Siswa Sekolah Dasar Melalui Permainan Tradisional, 2018, hlm. 234-247 
Kesan modern ditimbulkan oleh alat yang digunakan, cara bermain, serta tempat memainkannya. Meskipun bisa dimainkan dimana saja dan kapanpun asal ada jaringan internet, namun permainan modern seringnya dimainkan di dalam ruangan yang teduh dan nyaman yang sesuai keinginan. Dalam benak kebanyakan anak permainan modern merupakan permainan anak kota sedangkan permainan tradisional merupakan permainan yang kampungan dan sangat ketinggalan zaman. Cara memainkannya juga harus menguras tenaga dan berada di luar ruangan yang panas dan terik jika dilakukan di siang hari pada musim kemarau serta dapat menyebabkan penyakit jika dimainkan pada saat musim hujan tiba. ${ }^{2}$

Beberapa kemudahan dalam memainkan permainan modern membuat mereka lebih memilih permainan digital. Selain itu, orang tua juga mendukung anaknya agar bermain menggunakan permainan digital saja yang lebih modern dan aman. Orangtua bangga jika dapat memfasilitasi anak-anaknya dengan fasilitas yang canggih. Pertimbangan lainnya, anak lebih anteng di rumah dengan permainan digital tanpa harus keluar rumah yang membuat sikap anak agresif bergerak kesanakemari dan tidak jarang beberapa permainan tradisional menimbulkan cidera, baju kotor, dan membuat kecakepan. Inilah yang membuat orang tua berpikir simple dengan memberikan gadget untuk menyenangkan hati buah hatinya sebagai media permainan anak.

Dampak negatif dari game oline tanpa adanya pengontrolan dari dalam diri sendiri yaitu: memiliki daya tahan tubuh yang lemah akibat dari kurangnya aktivitas fisik, duduk terlalu lama, seringnya terlambat makan, sering terpapar sinar radiasi dari layar ponsel ataupun layar computer, dapat merusak perkembangan mental seseorang, menghambat proses pendewasaan diri dan mempengaruhi prestasi belajar. Lebih parahnya lagi, kecanduan game online menyebabkan sikap anak yang acuh tak acuh terhadap orang disekitar dan lingkungannya, yang terjadi di lingkungan sekolah maupun dirumah. Mereka seperti punya dunia nya sendiri yang sangat mengasikkan tanpa memperdulikan kejadian apa yang terjadi di sekelilingnya. Game online juga dapat menyebabkan menurunnya sopan santun. Dapat dilihat pada saat anak asyik bermain game online maka mereka akan Terhadap Keterampilan Anak Kelompok B TK IV Kecamatan Banjarsari Surakarta 2013/ 2014, Vol. 2, No.1, hlm. 1-7 
mengabaikan orang yang berada di dekatnya dan enggan mengajaknya berkomunikasi. Bahkan, saat orang tuanya sendiri sekalipun yang berbicara tak jarang diabaikan oleh para pecandu game online ini. Hal ini diperkuat oleh temuan Sari dan Mitsalia, bahwa gadget memberikan dampak negative yang membuat anak cenderung pendiam, lebih senang memainkan gadget nya daripada bermain langsung dengan temannya, terkadang mereka juga menirukan adegan kekerasan yang ada di game online, serta mereka bersikap acuh bila sudah didepan gadgetnya. Ini sungguh masalah yang sangat akut bagi para orangtua, pendidik, dan kita semua.

Nilai- nilai pendidikan yang terkandung dalam permainan anak tradisional menjadi tidak mampu berperan dalam pembentukan anak bangsa yang berbudaya dan berkarakter Indonesia sebagai akibat dari tidak dilestarikannya permainan tradisional pada anak. Jika hal ini dibiarkan, maka dapat mengakibatkan perkembangan karakternya menjadi karakter yang negative bagi anak. Oleh karenanya dibutuhkan upaya untuk meumbuhkan nilai- nilai karakter pada anak tanpa menghalangi aktivitas bermainnya ${ }^{3}$ Diperlukan upaya revitalisasi dan rekonstruksi permainan anak- anak tradisional yang tersebar diseluruh pelosok tanah air. Dunia pendidikan berkewajiban mentransformasikan nilai- nilai yang terkandung dalam permainan anak tradisional melalui serangkaian aktivitas pendidikan. ${ }^{4}$ Sekolah menjadi salat satu tempat yang cukup efektif untuk membina anak supaya memiliki karakter- karakter mulia. Salah satu upaya yang dapat dilakukan yaitu, dengan melakukan pembiasaan permainan tradisional di sekolah. Upaya ini dapat menjadi metode yang tepat utuk menumbuhkan nilai- nilai karakter siswa, karena apabila sekolah menerapkan pembiasan permainan tradisional pada siswa sejak usia sekolah dasar, diharapkan hal tersebut dapat mengurangi aktivitas bermain game online pada siswa.

Akhlak atau karakter dapat dibentuk melalui pembiasaan. Meskipun pada awalnya peserta didik terpaksa melakukan suatu perilaku tertentu, namun apabila dilakukan secara terus- menerus maka akan menjadi pembiasaan dan menjadi

\footnotetext{
${ }^{3}$ Nur Lailifitriyani, Retno Dian Pertiwi, dkk, Pembiasaan Permainan Tradisional Sebagai UpayaMenumbuhkan Nilai-nilai Karakter Pada Siswa Sekolah Dasar, 2018, hlm. 166- 171

${ }^{4}$ Fauzi, Pembentukan Karakter Anak Melalui Permainan Tradisional Cim- ciman, Jurnal Ilmiah VISI PPTK PAUDNI, Vol. 11, No. 2 Desember, 2016, hlm. 99- 109
} 
sebuah karakter yang tetap di dalam diri seorang peserta didik. Melalui pembiasaan bermain permainan tradisional ini, diharapkan nilai-nilai karakter positif yang ada di dalam permainan tradisional dapat dipahami dan dilaksanakan terus menerus oleh anak secara konsisten, selanjutnya dapat terinternalisasi dalam diri anak menjadi sebuah karakter. Kebiasaan bermain permainan tradisional diharapkan dapat menumbuhkan nilai-nilai karakter positif yang ada di dalam permainan tradisional. Mohammed 'Abed Al-Jabiri seorang ilmuan asal Maroko mengungkapkan bahwa perubahan harus berangkat dari dalam, dari tradisi sendiri, bukan dengan meminjam tradisi orang lain. Tawaran Al-Jabiri sebagai tawaran yang sangat menarik untuk direfleksikan dalam konteks kehidupan kebangsaan, sebagai bangsa yang kaya akan kebudayaan local dengan segala keunikan dan keragamannya.

Penelitian ini mengkaji salah satu jenis permainan anak tradisional yang berkembang di Sulawesi Tenggara dengan corak khas budaya yaitu Lojo/Palejo. Penelitian ini diharapkan dapat menjadi bagian proses rekonstruksi dan revitalisasi permainan anak tradisional yang semakin tidak popular ditengah- tengah hegemoni permainan- permainana anak modern berbasis elektronik. Permainan anak tradisional merupakan asset social- budaya bangsa yang harus dilestarikan agar nilai- nilai yang terkandung di dalamnya dapat tetap lestari dan berkontribusi secara optimal bagi terbentuknya manusia Indonesia seutuhnya.

\section{B. METODE PENELITIAN}

Metode yang digunakan dalam kajian ini menggunakan metode studi kepustakaan. Dimana studi kepustakaan merupakan kajian teroitis, referensi serta literatur ilmiah lainnya yang berkaitan dengan budaya, nilai dan norma yang berkembang pada situasi sosial yang diteliti. ${ }^{5}$ Berbeda dengan pengertian studi pustaka menurut Mardalis, studi pustaka ialah mengumpulkan data dengan bantuan berbagai macam material yang ada di perpustakaan seperti dokumen, buku, catatan, majalah, kisah-kisah sejarah dan sebagainya. Studi pustaka ini adalah metode penelitian dimana peneliti tidak harus turun langsung ke lapangan untuk bertemu dengan narasumber. Metode ini memperoleh data-data berdasarkan

5 Milya Sari dan Asmendri, Penelitian Kepustakaan (Library Reaserch) dalam Penelitian Pendidikan IPA, Jurnal Penelitian Bidang IPA dan Pendidikan IPA, Vol, 6 (1), . 2020, hlm. $41-53$ 
sumber-sumber perpustakaan. Di dalam buku Mestika Zed Metode Penelitian Kepustakaan, ada empat langkah dalam penelitain kepustakaan, diantaranya:

1. Menyiapkan alat perlengkapan, dalam penelitian ini perlengkapannya berupa pensil atau pulpen dan juga buku catatan

2. Menyusun blibiografi kerja, yaitua catatan mengenai bahan sumber utama yang akan dipergunakan untuk kepentingan penelitian

3. Mengatur waktu, waktu disini bisa satu jam, satu hari, satu bulan atau tergantung pada personal itu sendiri

4. Membaca dan membuat catatan penelitian, apa- apa saja yang dibutuhkan didalam penelitian. ${ }^{6}$

Teknis dan instrument pengumpulan data dalam penelitian ini adalah dokumentasi, yaitu mencari data mengenai hal- hal atau variabel yang berupa catatan, buku, makalah, atau artikel jurnal dan sebagainya. ${ }^{7}$

\section{HASIL DAN PEMBAHASAN}

Bagi usia anak sekolah dasar bermain dianggap sebagai belajar. Kegiatan bermain dapat menimbulkan kesenangan serta kepuasan bagi si anak. Bermain juga sebagai pengembangan kemampuan sosial yang nantinya mampu memberikan kesempatan untuk bereksplorasi, menemukan, belajar secara menyenangkan, berekreasi dan mengekspresikan perasaan mereka. ${ }^{8}$ Bermain dapat di anggap sebagai aktivitas terkait dengan keseluruhan diri anak, melalui permainan atau melalui bermain anak akan terdorong mempraktekkan keterampilannya yang dapat mengarahkan perekembangan kognitifnya, perkembangan psikomotorik dan juga perkembangan fisik. Pengalaman bermain akan mendorong anak lebih kreatif. Mulai dari perkemabangan emosi yang nantinya akan mengarah kepada kreativitas bersosialisasinya. ${ }^{9}$

Ada beberapa teori yang menjelaskan arti serta nilai dari permainan, diantaranya sebagai berikut :

6 Khatibah, Penelitian Kepustakaan, Jurnal Iqra', Vol. 5, No. 1 Mei, . 2011, hlm. 36- 39

7 Abdi Mirzaqon, Budi Purwoko, Studi Kepustakaan Mengenai Landasan Teori dan Praktik Konseling Expessive Writing, Jurnal Unesa, 2017, hlm. 1-8

${ }^{8}$ Rina Wijayanti, Permainan Tradisional Sebagai Media Pengembangan Kemampuan Sosial Anak, Jurnal Pendidikan Anak Usia Dini, Vol. 5, No. 1, 2014, hlm. 51-56

${ }^{9}$ Iis Nurhayati, Peran Permainan Tradisional Dalam Pembelajaran Anak Usia Dini, Jurnal EMPOWERMENT, Vol. 1, No. 2 September, . 2012, hlm. 39- 48 
a. Teori rekreasi oleh Schaller dan Nazaruz mereka menyatakan permainan itu sebagai kesibukan rekreatif, sebagai lawan dari kerja dan keseriusan hidup.

b. Teori pemunggahan oleh Herbert Spencer, permainan disebabkan oleh mengalir keluarnya energy, yaitu tenaga yang belum terpakai dan menumpuk pada diri anak.

c. Teori atavitis oleh Stanley Hall, permainan itu merupakan penampilan dari semua faktor hereditas, yaitu segala pengalaman jenis manusia sejarah akan diwariskan kepada anak keturunannya.

d. Teori biologis oleh Karl Groos, permainan itu mempunyai tugas biologis, yaitu melatih macam- macam fungsi jasmani dan rohani. ${ }^{10}$

Maka dapat disimpulkan bahwa bermain merupakan aktivitas mendasar anak yang dilakukan sendiri, bersama pendidik, keluarga, teman dan juga orangtua yang mana kegiatan tersebut dilakukan tanpa adanya paksaan dan dilakukan secara sukarela, menyenangkan dengan bermain, anak akan mampu memahami aturan, bekerjasama dan bersosialisasi. ${ }^{11}$

Permainan tradisional merupakan symbol dari pengetahuan yang tersebar melalui lisan dan mempunyai pasar moral dan manfaat di dalamnya. Menurut Pellegrini dan Naville Bannet bahwa permainan di definisikan menurut tiga matra : (1) Permainan sebagai kecenderungan, (2) Permainan sebagai konteks, dan (3) Permainan sebagai perlaku yang dapat diamati. Menurut Danandjaja, permainan tradisional adalah bentuk berupa permainan yang beredar secara lisan di antara anggota kolektif tertentu, berbentuk tradisional dan diwarisi turun menurun serta banyak mempunyai variasi. Permainan tradisional kadang tidak diketahui asalusulnya, siapa penciptanya dan darimana asalnya. Biasanya disebarkan melalui dari mulut ke mulut dan terkadang mengalami perubahan nama dan bentuk walaupun dasarnya sama. ${ }^{12}$

Permainan Tradisional juga dikenal sebagai permainan rakyat yang merupakan sebuah kegiatan rekreatif yang tidak hanya bertujuan untuk menghibur

\footnotetext{
${ }^{10}$ Oman Farhurohman, Hakikat Bermain dan Permainan Anak Usia Dini Di Pendidikan Anak Usia Dini (PAUD), Jurnal Pendidikan Anak Usia Dini, Vol. 2, No. 1 Januari- Juni, . 2017, hlm. 27- 36

${ }^{11}$ Naili Rohmah, Bermain dan Manfaatnya Dalam Perkembangan Anak Usia Dini, Jurnal Tarbaawi, Vol. 13, No. 2 Juli- Desember, 2016, hlm. 27- 36

12 Gustiana Megan Anggita, Baitul Mukarromah Siti \& Mohammad Arif Alif, Eksistensi Permainan Tradisional Sebagai Warisan Budaya Bangsa, Journal of Sport Science and Education (JOSSAE), Vol. 3, No.2 Oktober, 2018, hlm. 56-59
} 
diri, tetapi juga sebagai alat untuk memelihara hubungan dan kenyamanan sosial. Dengan demikian bermain merupakan suatu kebutuhan bagi anak. Jadi bermain bagi anak mempunyai nilai dan cirri yang penting untuk kemajuan perkembangan kehidupan sehari- hari termasuk dalam permainan tradisional. ${ }^{13}$ Permainan tradisional dianggap istimewa karena ada hal- hal yang membedakannya dengan permainan modern yang berkembang pada saat ini. Dimana permainan tradisional sebenarnya merupakan sebuah permainan yang baik untuk perkembangan karakter anak yang mempunyai sisi berimbang antara faktor psikis dengan faktor fisiknya, dengan perbandingan $50 \%$ - 50\%. Dalam artian bahwa semua permainan tradisonal mempunyai sisi yang lengkap untuk membantu perkembangan fisik dan psikis anak- anak. ${ }^{14}$

Permainan tradisional perlu mendapatkan perhatian khusus dan prioritas utama untuk dilindungi, dibina, dikembangkan, diperdayakan dan diwariskan. Agar permainan tradisional memiliki ketahanan dalam menghadapi unsure kebudayaan asing. Manfaat permainan tradisional bagi anak antara lain: (1) Anak akan terarah, (2) Permainan tradisional digunakan sebagai terapi terhadap anak, karena permainan tradisional membuat anak menjadi senang, ceria dan menyenangkan, dan (3) Anak semakin mudah bersosialisasi, karena dalam permainan tradisional anak dapat belajar berinteraksi, menghargai dan bersikap baik dengan orang lain. ${ }^{15}$

Permainan lojo/palejo ini merupakan salah satu jenis permainan tradisional anak yang sangat popular di Provinsi Sulawesi Tenggara. Permainan lojo/ palejo ini menggunakan alat yang terbuat dari tempurung kelapa yang dilubangi. Biasanya dimainkan oleh anak laki- laki, dan untuk anak perempuan bisa disebut dengan pebudo. ${ }^{16}$

Cara membuat permainan lojo/palejo tidak lah sulit:

a. Pertama-tama siapkan batok kelapa yang sudah tua

b. Kemudian belah lah batok kelapa tersebut menjadi dua bagian

\footnotetext{
${ }^{13}$ Asmida, Keberadaan Permainan Tradisional di Era Modernisasi di Desa Batu Belah Kabupaten Anambas, 2017, hlm. 1- 28

${ }^{14}$ Hikmah Prisia Yudiwinata, Pambudi Handoyo, Permainan Tradisional dalam Budaya dan Perkembangan Anak, Jurnal Paradigma, Vol. 2 No. 3, 2014, hlm. 1-5

${ }^{15}$ Nofrans Eka Saputri, Yun Nina Ekawati, Permainan Tradisional Sebagai Upaya Meningkatkan Kemampuan Dasar Anak, Jurnal Psikologi Jambi, Vol. 2, No. 2 Oktober, hlm. 48- 54
} 
c. Setelah itu di setiap bagian batok kelapa diberi lubang tepat dibagian tengahnya

d. Untuk kemudian dikaitkan pada seutas tali dan dihubungkan pada batok yang lain. Tali yang digunakan ialah tali yang memiliki sifat lentur sehingga mudah untuk digunakan untuk bermain.

Cara memainkan lojo/palejo pun bisa dibilang sangat sederhana.

a. Permainan ini dapat dimainkan sendiri ataupun bersama-sama. Jika dimainkan bersama-sama, terlebih dahulu dibuat garis strat dan garis finish. Permainan tradisonal lojo/palejo ini biasanya dimainkan dengan menggunakan rintagan. Setiap peserta diadu laju dengan melewati jalan yang sudah diberi rintangan, seperti tali yang melintang. Peserta yang menyentuh tali rintangan tersebut saat berjalan akan dianggap gagal.

b. Para pemain bersiap digaris start, kedua kaki diletakkan pada masingmasing batok kelapa, dengan ibu jari dan telunjuk pada jari kaki menjepit tali, sementara itu tangan memegang dan menarik tali

c. Kemudian Para pemain berjalan menggunakan lojo/palejo

d. Pemenang dari permainan ini adalah pemain yang pertama kali berhasil mencapai garis finish.

Meskipun bisa dikatakan sangat sederhana, memainkan lojo/palejo ini sangat diperlukan keseimbangan tubuh, selain itu dibutuhkan kekompakkan gerak tangan dan kaki untuk bisa berjalan menggunakan lojo/palejo dengan sempurna. Ada banyak tujuan bermain lojo/palejo bagi anak. Pertama, untuk mengisi kegiatan pada waktu luang sehingga waktu yang dimiliki anak tidak terbuang begitu saja. Kedua, anak jadi memperoleh kesenangan karena bermain diluar rumah bersama teman- temannya. Ketiga, dengan bermain anak berlajar nilai - nilai kehidupan dan nilai- nilai budaya serta belajar mengembangkan seluruh aspek dalam dirinya.bermain lojo/palejo.

Bermainan lojo/palejo bagi anak memiliki banyak manfaat, anak akan terlatih untuk disiplin, bertoleransi, bekerja keras, kreatif, mandiri, semangat, cinta damai, dan lain sebagainya. Dengan bermain lojo/ palejo ini anak juga 
terlatih motorik kasar serta halusnya. Dengan banyak bergerak, ia akan memiliki otot- otot tubuh yang terbentuk secara baik dan lebih sehat. ${ }^{17}$

Gambar 1. Permainan Lojo/Palejo

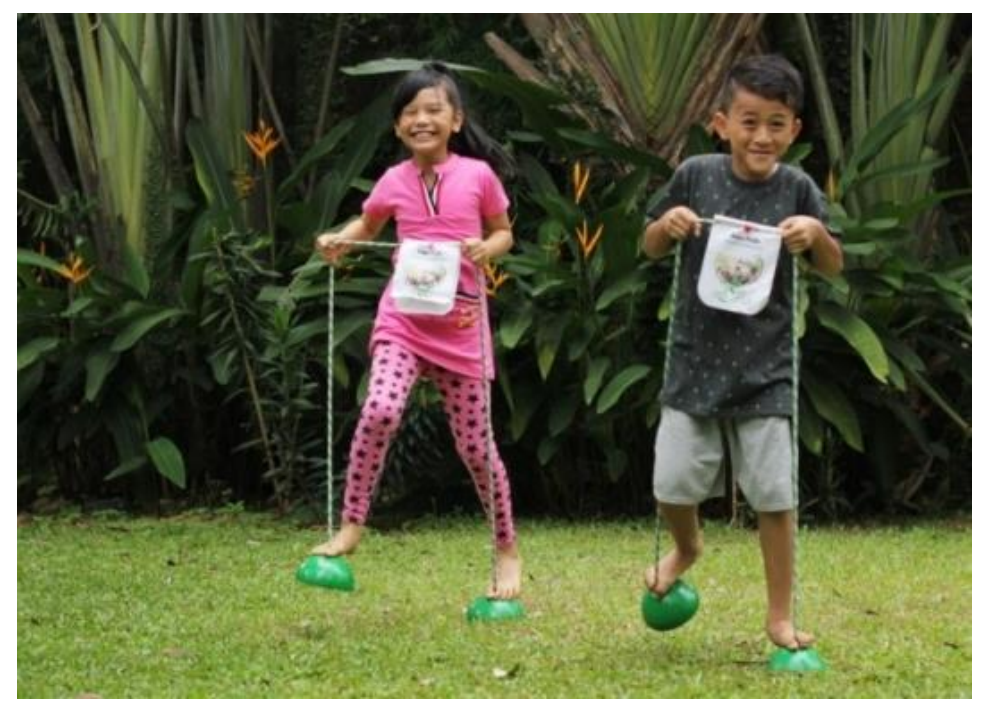

Permainan Lojo/Palejo perlu diperhatikan agar ke depannya tetap dapat diturunkan pada generasi selanjutnya. Terutama dalam perkembangan zaman yang seperti sekarang ini, yang mana budaya barat dan moderenisasi yang di konsumsi sehari-hari oleh anak-anak generasi muda. Dengan hadirnya modernisasi menuntut pesatnya perkembangan teknologi dan informasi mengakibatkan permainan Lojo/Palejo terkesan kuno. Masuknya modernisasi dapat mengubah pola pikir masyarakat terhadap perkembangan budaya sendiri. ${ }^{18}$

Secara etimologis, kata karakter berasal dari bahasa Yunani, yaitu charassein yang berarti mengukir. Makna ini dapat dikaitkan dengan persepsi bahwa karakter adalah lukisan jiwa yang termanifestasi dalam perilaku. Sedangkan karakter dalam Kamus Besar Bahasa Indonesia diartikan sebagai "tabiaat", sifat- sifat kejiwaan, akhlak atau budi pekerti yang membedakan seseorang dengan yang lain. Karakter juga merupakan kepribadian seseorang yang meliptu sifat, perilaku, akhlak watak tabiat dan budi pekerti. Karakter memiliki sifat yang tetap. Maka dari itu, karakter seseorang harus dibentuk sejak

17 Juwairiah, Permainan Tradisional Aceh Sebagai Media Untuk Meningkatkan Kesehatan dan Kecerdasan Anak Usia Dini, Jurnal Pendidikan Anak, Vol. 1, No. 2 JanuariJuni, 2016, hlm. 119- 133

18 Afrinel Okwita, Siska Permata Sari, Eksistensi Permainan Tradisional Egrang Pada Masyarakat Mongga Kecamatan Galang Kota Batam, Jurnal Program Studi Pendidikan Sejarah, Vol. 4, No. 1, 2019, hlm. 19- 33 
usia kanak- kanak agar terbiasa berperilaku positif. Karena kegagalan dalam membentuk karakter sejak kanak- kanak akan menimbulkan masalah perilaku dimasa yang akan datang. Karakter anak bisa terbentuk karna pengaruh dari dalam diri anak tersebut dan lingkungan dimana anak tersebut bertempat tinggal. ${ }^{19}$

Melengkapi uraian diatas pendapat lain dikemukakan oleh Wibowo tidak sulit menemukan nilai- nilai luhur budaya dalam pendidikan karakter, karena bangsa Indonesia dikenal sebagai bangsa yang masih menjunjung tinggi adat dan budaya luhur ketimuran. Nilai-nilai luhur itu merupakan aspek utama yang diterapkan kepada peserta didik melalui pendidikan karakter. ${ }^{20}$ Pengertian karakter diatas tampaknya sama dengan pengertian akhlak dalam pandagan islam. Menurut pandangan Islam, akhlak adalah sifat yang berada dalam jiwa seserang yang mendorong orang tersebut untuk melakukan perbuatan secara tidak sadar dan tanpa melalui pemikiran dan pertimbangan terlebih dahulu. Perbuatan seseorang akan menjadi karakter atau akhlak jika dilakukan secara berulang-ulang dan menjadi kebiasaan ${ }^{21}$ Pengimplemasikan pendidikan karakter tentunya membutuhkan peran aktif orang tua, pendidik dan masyarakat. Menurut Lickona, sekolah dan keluarga adalah mitra terpenting dalam membentuk karakter anak, meskipun sekolah dapat memperbaiki tingkah laku siswa ketika mereka berada di lingkungan sekolah dan bukti menunjukkan bahwa sekolah mampu melakukannya, namun sangat memungkikan dampak yang mampu bertahan lama pada karakter anak akan lenyap apabila nilai- nilai yang diajarkan di sekolah tidak di dukung di lingkungan keluarganya.

Karakter tidak akan berjalan jika tanpa ada faktor di dalamnya, faktor pembentukan karakter ada dua baik itu faktor internal maupun faktor eksternal. Yang terdapat di dalam faktor internal ialah kumpulan unsure kepribadian yang mempengaruhi perilaku manusia berupa dorongan biologi, kebutuhan psikologi dan kebutuhan pemikiran. Sedangkan faktor eksternal ialah faktor yang berada di

${ }^{19}$ Asriyati Nadjamuddin, Membangun Karakter Anak Lewat Permainan Tradisional Daerah Gorontalo, Jurnal Manajemen Pendidikan Islam, Vol. 4, No. 2 Agustus, 2016, hlm. 7479

${ }^{20}$ Clara Tesalonika, Analisis Nilai Karakter Dalam Permainan Tradisional Kucing Tikus, Jurnal Penelitian Dalam Bidang Kependidikan Usia Dini, Vol. 9. No. 1, hlm. 33- 49

${ }^{21}$ Tuti Andriani, Permainan Tradisional Dalam Membentuk Karakter Anak Usia Dini, Jurnal Sosial Budaya, Vol. 9, No. 1 Januari- Juli, 2012, hlm. 121- 136 
luar manusia namun dapat mempengaruhi karakternya berupa sosial, budaya, keluarga serta lingkungan di sekitanrnya. Karakter hanya dapat diukur ketika keadaan manusia sedang dalam keadaan sadar saja. ${ }^{22}$

Fungsi pembentukan karakter sendiri ialah untuk mengembangkan potensi dasar seseorang agar dapat berperilaku baik serta berberpikiran yang positif. Dengan kata lain pembentukan karakter ialah mengembangkan serta membangun perilaku anak bangsa yang multicultural. Di era modern seperti sekarang ini pendidikan mencetuskan sebuah pendidikan dengan selogan pendidikan karakter. Hal itu menunjukkan bahwa karakter menjadi sangat penting untuk diberikan bagi anak. Pendidikan yang diberikan kepada anak usia Sekolah Dasar (SD) dapat membentuk perilaku positif, dapat menimbulkan interaksi yang baik antar gurunya, dapat mengelola emosinya dirinya dengan baik, percaya diri yang lebih, serta dapat berinteraksi sosial dengan kawannya termasuk kemampuan akademik nya.

Terdapat berbagai macam karakter, namun yang ingin kita bahas kali ini ialah mengenai karakter kerja keras. Karakter kerja keras merupakan karakter yang ada di dalam diri siswa, menurut Hayoto, pengertian kerja keras adalah berusaha dengan gigih atau sungguh- sungguh untuk mencapai kesuksesan dan tidak mengenal putus asa. Menurut Angelica Ardi, Kerja keras sendiri memiliki ciri yaitu tekun dan ulet, teliti dan cermat, menghargai waktu, bekerja cerdas, disiplin, sabar, ikhlas dan pantang menyerah. ${ }^{23}$

Menurut Amini, secara umum terdapat enam cara dalam menumbuhkan karakter pada anak salah satunya ialah karakter kerja keras, yaitu :

a. Menyiapkan diri menjadi contoh yang baik bagi anak

Setiap anak perlu contoh yang baik dari ayah dan ibunya, sikap baik maupun buruk merupakan cerminan dari lingkungan terdekat yang paling banyak ditiru oleh anak. Menjadi contoh bagi anak merupakan pekerjaan utama yang harus dilakukan oleh para orang tua

\footnotetext{
${ }^{22}$ Arie Ramadhani, Identifikasi Nilai- nilai Pendidikan Karakter Dalam Permainan Anak Tradisional, Prosiding Seminar Nasional IPTEK Olahraga, 2018, hlm. 6-10

${ }^{23}$ Nita Handayani Warih, Sumaryati, Upaya Orang Tua dalam Menanamkan Karakter Kerja Keras Anak Usia Remaja, Jurnal Citizenship, Vol. 4, No. 1 Juli, 2014, hlm. 27-38
} 
b. Melibatkan anak dalam pekerjaan

Anak dapat diajak andil dalam pekerjaan orang tua di rumah sehingga tumbuh rasa tanggung jawab dalam bekerja keras

c. Terlibat dalam kehidupan sekolah anak

Setelah lingkungan keluarga, lingkungan sekolah merupakan bagian yang memiliki peranan penting kedua dalam kehidupan anak. Keberhasilan anak dalam mengatasi berbagai permasalahannya di sekolah akan memperkokoh anak dan menanamkan rasa percaya diri dalam menatap masa depan.

d. Bersikap tegas dan konsisten

Konsisten merupakan keselarasan anatara apa dinyatakan melalui tindakan dengan apa yang ia lakui. Orang tua adalah panutan yang utama bagi anak, seorang panutan yang baik harus selalu bersikap konsisten pada apa yang telah ditanamkannya.

e. Memberi hukuman dengan kasih saying Hukuman yang mendidik merupakan salah satu cara bagi manusia untuk belajar

f. Belajar mendengarkan anak

Oleh karena itu orang tua sebaiknya meiliki waktu khusus untuk berdiskusi dengan anaknya.

Diantara sarana terbaik untuk mengokohkan karakter anak- anak adalah melalui permainanan yang melibatkan fisik maupun pikira anak. Rogers dan Sawyer's mengemukakan bahwa hingga pada anak usia sekolah, bermain bagi anak memiliki arti yang sangat penting. Adapun nilai- nilai penting dalam bermain bagi anak, yaitu sebagai berikut:

a. Meningkatkan kemampuan problem solving pada anak.

b. Menstimulasi perkembangan bahasa dan kemampuan verbal

c. Mengembangkan keterampilan sosial

d. Merupakan wadah pengekspresian emosi

Selain itu, dalam Best Play menyebutkan bahwa peran bermain pada anak berdampak pada sejumlah bidang kehidupan anak, yaitu sebagai berikut:

a. Bermain mempunyai peran yang penting dalam belajar. Dalam hal ini, bermain dapat melengkapi keingatan sekolah anak, yang dapat member kesempatan kepada anak untuk memahami, meresapi, dan meberi arti kepada apa yang 
mereka pelajari dalam setting pendidikan formal. Secara khusus, bermain menjadi penting yaitu membantu anak untuk memperoleh "bukan informasi khusus melainan mindset umum dalam pemecahan masalah"

b. Bermain dapat mendukung perkembangan fisik dan kesehatan mental yang baik. Bermain memfasilitasi anak dalam beraktivitas fisik, meliputi berolah raga, serta mengembangkan keterampilan dalam pertumbuhan anak.

c. Bermain member kesempatan untuk menguji anak dalam menghadapi tantangan dan bahaya.

Berdasarkan uraian di atas, dapat disimpulkan bahwa permainan tradisional memang berbeda dengan permainan yang ada di gadget atau kata lain game online. Tidak hanya dari kesan yang ditimbulkannya, tetapi juga dari maka dan pengaruhnya pada anak- anak di indoesia. Oleh karenanya dapat dipahami, bahwa pemilihan permainan dalam hal ini akan berpengaruh terhadap perkembangan anak nantinya. Disini peran orang tualah yang sangat penting dalam memilihkan atau memberikan permainan kepada anaknya, apakah permainan digital yang kesannya modern dan canggih namun berdampak negative bagi fisik dan karakter anak atau kah permainan tradisional yang kesannya kampungan dan bisa dibilang ketinggalan zaman tetapi berdapak positif bagi karakter dan tumbuh kembang anak dan akan menentukkan karakter yang tercipta pada anak-anak Indonesia, generasi penerus dan harapan bangsa. ${ }^{24}$

Cara pembentukan karakter kerja keras dapat diamati melalui langkahlangkah permainan tradisional lojo/palejo sebagai berikut,:

a. Permainan ini dapat dimainkan sendiri ataupun bersama- sama. Jika dimainkan bersama-sama, terlebih dahulu dibuat garis strat dan garis finish. Permainan tradisonal lojo/palejo ini biasanya dimainkan dengan menggunakan rintagan. Setiap peserta diadu laju dengan melewati jalan yang sudah diberi rintangan, seperti tali yang melintang. Peserta yang menyentuh tali rintangan tersebut saat berjalan akan dianggap gagal. Jika dilihat dari langkah permainanya, di tahap awal saja kita sudah dapat melihat memainkannya penuh rintangan yang artinya

${ }^{24}$ Haerani Nur, Membangun Karakter Anak Melalui Permainan Anak Tradisional, Jurnal Pendidikan Karakter, Tahun III, No. 1 Februari, 2013, hlm. 88- 94 
peserta didik harus bekerja keras agar dapat lolos dari rintangan di dalam permainan tersebut.

b. Para pemain bersiap digaris start, kedua kaki diletakkan pada masing-masing batok kelapa, dengan ibu jari dan telunjuk pada jari kaki menjepit tali, sementara itu tangan memegang dan menarik tali.

c. Kemudian Para pemain berjalan menggunakan lojo/ palejo.

d. Pemenang dari permainan ini adalah pemain yang pertama kali berhasil mencapai garis finish.

Ditahap selanjutnya peserta didik bekerja keras agar dapat menjalankan lojo palejo tersebut sampai garis finish dan berusaha sekeras mungkin agar tidak kalah dengan pemain yang lain. Dapat kita simpulkan bahwa melalui permainan lojo/ palejo dapat melatih peserta didik untuk mengembangkan karakter kerja keras dengan cara yang menyenangkan dan masih dalam dunia bermain mereka.

\section{SIMPULAN}

Game online sebagai permainan modern memang memiliki kesan canggih dan mutakhir namun permainan ini menimbulkan banyak efek negative dalam pembentukan karakter anak, khusunya pada siswa Sekolah Dasar. Kecanduan game online, dapat mengakibatkan siswa susah bergaul, tidak peduli dengan lingkungannya, lupa waktu, dan meniru adegan kekerasan dari game online, serta dampak yang paling buruk yang lebih besar bisa terjadi jika siswa memainkan permainan yang terdapat konten pornografi.

Permainan tradisional memang sudah terlalu using dan kuno, namun jika dilihat dari manfaatnya yang begitu besar maka permainan ini perlu dihadirkan kembali dalam kehidupan anak- anak saat ini. Ini smeua mengingat dalam permainan tradisional banyak sekali nilai-nilai karakter atau moral yang ditanamkan saat memainkannya. Anak dapat belajar bersosialisasi dengan lingkungannya, berinteraksi secara langsung dengan teman- temannya, menjunjung kerjasama, gotong- royong, kejujuran, dan masih banyak lagi nilai luhur yang terkandung di dalam permainan tradisional.

Permainan Lojo/palejo dapat dipergunakan untuk melatih dan menstimulus perkembangan anak dalam beragam aspek secara holistik- integratif, baik secara fisik, motorik, bahasa, kognitif, sosial ekonomi, dan moral. Selain itu 
dapat dipergunakan untuk menanamkan dan membentuk nilai- nilai budaya dan membangun karakter anak seperti jujur, disiplin kreaktif, mandiri, kerja keras, tanggungjawab, kepedulian sosial, semangat, mengahargai prestasi, bersahabat, komunikatif, cinta damai dan musyawarah. Oleh karena itu, orang tua dan pendidik anak Sekolah Dasar dapat mengoptimalkan permainan tradisional khusunya Lojo/palejo untuk perkembanagan dan pembentukan karakter anak. Permainan ini dapat dipergunakan untuk evaluasi perkembangan dan karakter anak, karena di dalam kegiatan bermain ini, perilaku yang tampil lebih murni, alami dan apa adanya tanpa dibuat-buat. 


\section{DAFTAR PUSTAKA}

Ambaryani Novita, Yustinus Ngadino, Sujana Yudianto, Efektivitas Permainan Tradisional Terhadap Keterampilan Anak Kelompok B TK IV Kecamatan Banjarsari Surakarta 2013/2014

Andriani Tuti, Permainan Tradisional Dalam Membentuk Karakter Anak Usia Dini, Jurnal Sosial Budaya, 2012

Anggita Gustiana Megan, Mukarromah Siti Baitul \& Alif Mohammad Arif, Eksistensi Permainan Tradisional Sebagai Warisan Budaya Bangsa, Journal of Sport Science and Education (JOSSAE), 2018

Asmida, Keberadaan Permainan Tradisional di Era Modernisasi di Desa Batu Belah Kabupaten Anambas, 2017

Fauzi, Pembentukan Karakter Anak Melalui Permainan Tradisional Cim- ciman, Jurnal Ilmiah VISI PPTK PAUDNI, 2016

Farhurohman Oman, Hakikat Bermain dan Permainan Anak Usia Dini Di Pendidikan Anak Usia Dini (PAUD), Jurnal Pendidikan Anak Usia Dini, 2017

Handayani Nita Warih, Sumaryati, Upaya Orang Tua dalam Menanamkan Karakter Kerja Keras Anak Usia Remaja, Jurnal Citizenship, 2014

Huda Wafiq Nurul, Pembentukkan Karakter Pada Siswa Sekolah Dasar Melalui Permainan Tradisional, 2018

Juwairiah, Permainan Tradisional Aceh Sebagai Media Untuk Meningkatkan Kesehatan dan Kecerdasan Anak Usia Dini, Jurnal Pendidikan Anak, 2016

Khatibah, Penelitian Kepustakaan, Jurnal Iqra', 2011

Lailifitriyani Nur, Pertiwi Retno Diani, dkk, Pembiasaan Permainan Tradisional Sebagai Upaya Menumbuhkan Nilai-nilai Karakter Pada Siswa Sekolah Dasar, 2018

Mirzaqon Abdi, Purwoko Budi, Studi Kepustakaan Mengenai Landasan Teori dan Praktik Konseling Expessive Writing, Jurnal Unesa, 2017

Nadjamuddin Asriyati, Membangun Karakter Anak Lewat Permainan Tradisional Daerah Gorontalo, Jurnal Manajemen Pendidikan Islam, 2016

Nur Haerani, Membangun Karakter Anak Melalui Permainan Anak Tradisional, Jurnal Pendidikan Karakter, 2013 
Nurhayati Iis, Peran Permainan Tradisional Dalam Pembelajaran Anak Usia Dini, Jurnal EMPOWERMENT, 2012

Okwita Afrinel, Sari Siska Permata, Eksistensi Permainan Tradisional Egrang Pada Masyarakat Mongga Kecamatan Galang Kota Batam, Jurnal Program Studi Pendidikan Sejarah, 2019

Ramadhani Arie, Identifikasi Nilai- nilai Pendidikan Karakter Dalam Permainan Anak Tradisional, Prosiding Seminar Nasional IPTEK Olahraga, 2018

Rohmah Naili, Bermain dan Manfaatnya Dalam Perkembangan Anak Usia Dini, Jurnal Tarbaawi, 2016

Saputri Nofrans Eka, Ekawati Yun Nina, Permainan Tradisional Sebagai Upaya Meningkatkan Kemampuan Dasar Anak, Jurnal Psikologi Jambi

Milya Sari dan Asmendri, Penelitian Kepustakaan (Library Reaserch) dalam Penelitian Pendidikan IPA, Jurnal Penelitian Bidang IPA dan Pendidikan IPA, 2020

Tesalonika Clara, Analisis Nilai Karakter Dalam Permainan Tradisional Kucing Tikus, Jurnal Penelitian Dalam Bidang Kependidikan Usia Dini

Wijayanti Rina, Permainan Tradisional Sebagai Media Pengembangan Kemampuan Sosial Anak, Jurnal Pendidikan Anak Usia Dini, 2014

Yudiwinata Hikmah Prisia, Handoyo Pambudi, Permainan Tradisional dalam Budaya dan Perkembangan Anak, Jurnal Paradigma,2014 